\title{
Carbon and nitrogen isotopic composition of red deer (Cervus elaphus) collagen as a tool for tracking palaeoenvironmental change during the Late-Glacial and Early Holocene in the northern Jura (France)
}

\author{
Dorothée Drucker $^{\mathrm{a}}$, Hervé Bocherens ${ }^{\mathrm{a}, *}$, Anne Bridault ${ }^{\mathrm{b}}$, Daniel Billiou ${ }^{\mathrm{c}, 1}$ \\ a Laboratoire de Paléontologie, Institut des Sciences de l'Evolution, UMR 5455 du CNRS, Université Montpellier 2, case courrier 064, \\ Place Eugène Bataillon, F-34095 Montpellier cedex 05, France \\ b Equipe d'Archéologie environnementale, UMR 7041 du CNRS, Maison de l'Archéologie et de l'Ethnologie, case courrier 23, \\ 21 Allée de l'Université, F-92023 Nanterre Cedex, France \\ c Laboratoire de Biogéochimie Isotopique, UMR 7618 du CNRS, Université Paris 6, 4 Place Jussieu, F-75252 Paris cedex 05, France
}

\begin{abstract}
Red deer bone collagen from Rochedane in the Jura (France) was analysed for carbon and nitrogen isotopic composition. The specimens range in ${ }^{14} \mathrm{C}$ age from about 13000 to $8000 \mathrm{yr} \mathrm{BP}$ (uncalibrated), and cover the LateGlacial and Early Holocene, a time period during which climatic conditions shifted from periglacial to temperate. The carbon isotopic compositions of red deer collagen suggest changes in the vegetation cover around the site that are consistent with other palaeoenvironmental indicators, such as the palynological record in the Jura. The nitrogen isotopic compositions exhibit a large range of around $6 \%$ interpreted as reflecting changes in the intensity of $\mathrm{N}$ cycling coeval to vegetation changes. Red deer bone collagen appears thus as a valuable proxy for reconstructing palaeoenvironmental changes in continental western Europe during the Late-Glacial and Holocene.
\end{abstract}

Keywords: carbon-13; Cervus; collagen; Late-Glacial; nitrogen-15; palaeoenvironment

\section{Introduction}

Late-Glacial and Early Holocene times, around

\footnotetext{
${ }^{1}$ Present address: Laboratoire de Biogéochimie des Milieux Continentaux, UMR 7618 du CNRS, INAPG, EGER-INRA, F-78026 Thiverval-Grignon, France.

* Corresponding author.

E-mail address: bocheren@isem.univ-montp2.fr

(H. Bocherens).
}

13000 to 8000 years ago, witnessed very important palaeoclimatic changes. In western Europe, the climatic context shifted from glacial to temperate conditions in a succession of relative warming and cooling episodes (e.g. Magny, 1995; Björk et al., 1998; Amman et al., 2000). These environmental changes were contemporaneous with important alterations in human habitat conditions and ways of life (e.g. Smith, 1992; Floss, 2000; Leesch, 2000). The palaeoenvironmental changes 
that occurred in the Jura mountainous area of northeastern France are very well documented during this period (e.g. de Beaulieu et al., 1994; Bégeot et al., 2000; Richard and Bégeot, 2000; Richard et al., 2000). For instance, palynological records of peat and lake deposits have been used as proxies for vegetational reconstruction, and the isotopic signatures of carbonates from lake deposits have provided quantitative palaeoclimatic reconstructions. However, these proxies do not yield direct information on continental mammal palaeobiology and human activities. Variations in isotopic signatures are also recorded in animal bones. Bone collagen carbon and nitrogen isotopic signatures of herbivorous mammals have been used to reconstruct continental palaeoenvironmental fluctuations in tropical areas (e.g. Ambrose and DeNiro, 1989; Fernandez et al., 1991; Lee-Thorp and Beaumont, 1995; Gröcke et al., 1997; Pate and Noble, 2000). Indeed, under such climatic conditions, variations of carbon isotopic compositions reflect the ratio of $\mathrm{C}_{4}$ grasslands relative to $\mathrm{C}_{3}$ woodlands whilst nitrogen isotopic variations are linked to aridity.

The goal of the present paper is to test the ability to use carbon and nitrogen isotopic compositions in mammal bone collagen as palaeoenvironmental indicators in more temperate areas where the $\mathrm{C}_{4}$ plant biomass is negligible or even absent (Mateu Andrès, 1993) and where aridity variations are not as pronounced as in tropical regions. Red deer (Cervus elaphus) has been chosen as the test species due to the large number of skeletal remains belonging to this species in LateGlacial archaeological sites from western Europe (Bridault, 1997; Bridault and Chaix, 2002) and the large ecological flexibility of this species (e.g. Heptner et al., 1989). Investigating a limited area through time minimises the effects of parameters other than environmental changes. During the 5000 years represented by the archaeological deposits in the site of Rochedane, the surrounding environment shifted from a recently deglaciated area to temperate forest through the intermediate stages of tundra and boreal forest (Richard and Bégeot, 2000).

\section{Materials and methods}

The site of Rochedane $\left(47^{\circ} 21^{\prime} \mathrm{N}, 6^{\circ} 46^{\prime} \mathrm{E}\right)$ is located ca. $25 \mathrm{~km}$ south of the town of Montbeliard on the left bank of the Doubs River (Fig. 1). It is a rock-shelter dug into a calcareous cliff about $15 \mathrm{~m}$ high, at an altitude of $355 \mathrm{~m}$ above sea level in an area where the neighbouring plateaus rise to $700 \mathrm{~m}$ above sea level.

Excavation of Rochedane by André Thévenin

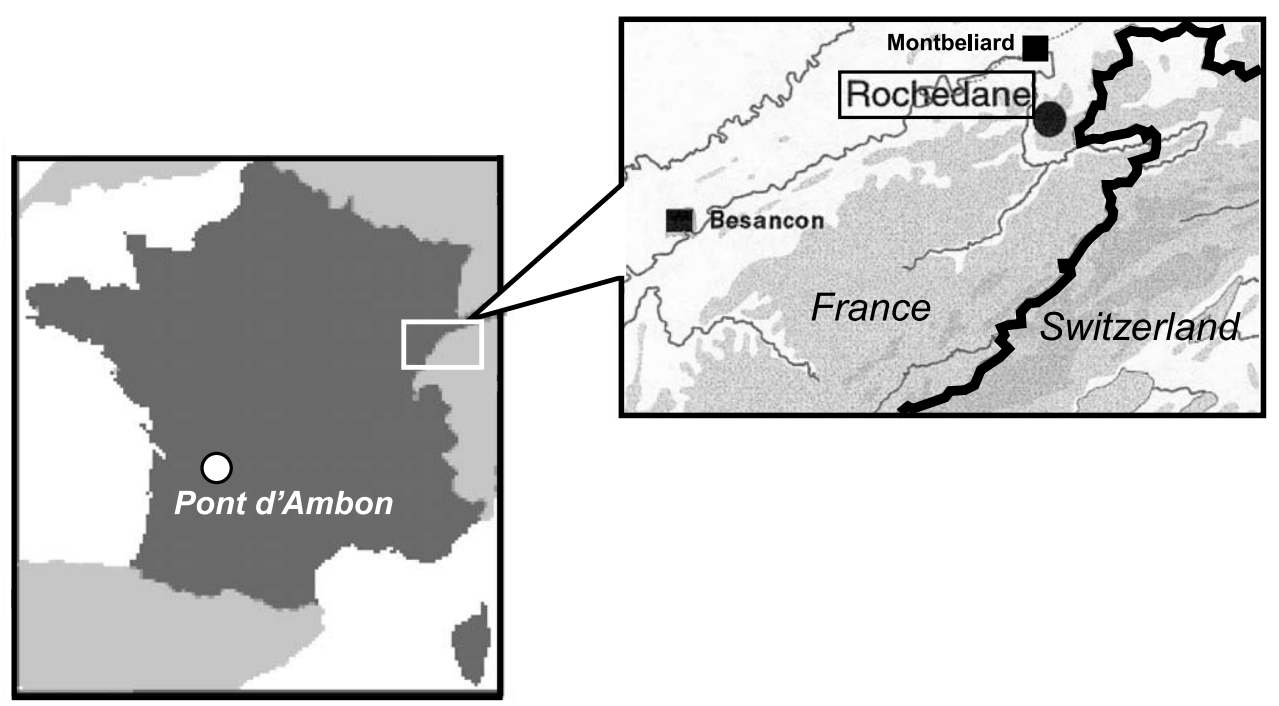

Fig. 1. Map of France showing the locations of the sites mentioned in the text; insert, detailed map of Rochedane. 
Table 1

Characteristics of the stratigraphic layers excavated at the site of Rochedane

\begin{tabular}{lllllll}
\hline Layer & Age BP & Age cal BC $(2 \sigma)$ & Laboratory number (ref) & $\%$ NISP red deer & Chronoclimatic zone & Culture \\
\hline D1 & $11060 \pm 470$ & $12145-9603$ & Ly-1193 (1) & 94.7 & Bölling & Magdalenian \\
& $12420 \pm 75$ & $13462-12185$ & Oxa-8030 (2) & & \\
C'1 $^{\prime} 11090 \pm 200$ & $11816-10699$ & Ly-1192 (1) & 95.0 & Bölling & Early Azilian \\
B & $10730 \pm 190$ & $11201-10151$ & Ly-1194 (1) & 91.3 & Alleröd & Azilian \\
A4 & $9210 \pm 120$ & $8746-8210$ & GIF-2530 & 84.8 & Younger Dryas & Azilian \\
A3 & & & & 58.5 & Preboreal & Early Mesolithic \\
A2 & & & 55.8 & Boreal & Mesolithic \\
\hline
\end{tabular}

Reference numbers stand for: (1) Evin et al. (1978); (2) Bridault et al. (2000). All radiocarbon dates have been calibrated according to the calibration dataset from Stuiver et al. (1998), using the software calib4.3. Cultural attribution is based on Thévenin and Sainty (1998). The \%NISP (number of identifiable fragments of bone) for red deer are adapted from Bridault (1990).

and Jean Sainty (1968-1976) identified several archaeological layers ranging between ca. 12500 and 8000 yr BP (e.g. Thévenin, 1982; Thévenin and Sainty, 1998; Table 1). All the layers yielded skeletal remains of red deer, Cervus elaphus (Bridault, 1990). The proportion of red deer in the total ungulate skeletal remains is very high in layers D1 to A4, decreasing in layers A3 and A2 (Table 1; Bridault, 1990).

Red deer bones have been selected to represent different individuals using the following sampling protocole: when several samples had been selected for one layer, specimens from the same anatomical part were used, which guaranties that no in-

Table 2

List of isotopic results obtained on red deer bone collagen from Rochedane

\begin{tabular}{|c|c|c|c|c|c|c|c|c|}
\hline Sample number & Piece & Layer & $\begin{array}{l}\text { Yield } \\
\left(\mathrm{mg} \cdot \mathrm{g}^{-1}\right)\end{array}$ & $\% \mathrm{C}$ collagen & $\% \mathrm{~N}$ collagen & $\mathrm{C} / \mathrm{N}$ & $\begin{array}{l}\delta^{13} \mathrm{C} \\
(\% 0)\end{array}$ & $\begin{array}{l}\delta^{15} \mathrm{~N} \\
(\% 0)\end{array}$ \\
\hline RCD500 & left radius & $\mathrm{D} 1$ & 30.0 & 42.3 & 15.5 & 3.2 & -19.9 & 0.8 \\
\hline RCD900 & left metatarsal & $\mathrm{C}^{\prime} 1$ & 18.8 & 40.3 & 14.6 & 3.2 & -20.1 & 1.8 \\
\hline RCD1000 & left metatarsal & $\mathrm{C}^{\prime} 1$ & 29.0 & 42.5 & 15.4 & 3.2 & -20.7 & 2.5 \\
\hline RCD1100 & left metatarsal & $\mathrm{C}^{\prime} 1$ & 19.2 & 42.0 & 15.3 & 3.2 & -21.9 & 3.0 \\
\hline RCD1200 & left metatarsal & $C^{\prime} 1$ & 6.2 & 38.9 & 14.4 & 3.1 & -19.9 & 1.3 \\
\hline RCD1300 & left metatarsal & $C^{\prime} 1$ & 10.2 & 37.8 & 13.9 & 3.2 & -20.6 & 2.0 \\
\hline RCD1400 & left metatarsal & $\mathrm{C}^{\prime} 1$ & 9.4 & 41.0 & 15.0 & 3.2 & -20.7 & 0.4 \\
\hline $\mathrm{RCD} 2300$ & left metatarsal & B & 10.2 & 38.5 & 14.2 & 3.2 & -20.8 & 1.6 \\
\hline $\mathrm{RCD} 2400$ & left metatarsal & B & 8.6 & 38.9 & 13.3 & 3.2 & -20.6 & 3.1 \\
\hline $\mathrm{RCD} 2500$ & left metatarsal & B & 16.5 & 40.0 & 14.6 & 3.2 & -21.2 & 2.6 \\
\hline RCD2600 & left metatarsal & B & 33.2 & 38.8 & 14.0 & 3.2 & -20.0 & 2.3 \\
\hline $\mathrm{RCD} 2700$ & left metatarsal & B & 12.2 & 38.2 & 14.2 & 3.2 & -20.9 & 1.6 \\
\hline $\mathrm{RCD} 2800$ & left metatarsal & B & 25.9 & 40.3 & 14.7 & 3.2 & -20.5 & 1.3 \\
\hline $\mathrm{RCD} 4700$ & left metatarsal & A4 & 31.7 & 39.7 & 14.8 & 3.1 & -19.5 & 1.4 \\
\hline RCD4800 & left metatarsal & A4 & 22.8 & 40.7 & 14.7 & 3.2 & -20.6 & 1.3 \\
\hline RCD4900 & left metatarsal & A4 & 24.1 & 39.9 & 14.8 & 3.2 & -20.0 & 1.3 \\
\hline RCD5000 & left metatarsal & A4 & 22.8 & 39.5 & 14.3 & 3.2 & -20.3 & 0.4 \\
\hline RCD5100 & left metatarsal & A4 & 22.3 & 39.8 & 14.7 & 3.2 & -20.0 & 0.2 \\
\hline RCD6200 & left metatarsal & A3 & 14.7 & 38.8 & 14.2 & 3.2 & -22.5 & 3.5 \\
\hline RCD6300 & left metatarsal & A3 & 22.8 & 39.1 & 14.3 & 3.2 & -23.4 & 4.7 \\
\hline RCD6400 & left metatarsal & A3 & 9.6 & 36.8 & 13.4 & 3.2 & -21.5 & 3.8 \\
\hline RCD6500 & left metatarsal & A3 & 29.4 & 40.5 & 14.6 & 3.2 & -23.0 & 5.2 \\
\hline RCD10100 & right metatarsal & A2 & 26.6 & 37.4 & 13.5 & 3.2 & -22.8 & 5.8 \\
\hline RCD10200 & right metatarsal & A2 & 16.2 & 38.2 & 14.2 & 3.1 & -22.7 & 4.3 \\
\hline RCD10300 & right metatarsal & A2 & 15.9 & 38.1 & 14.0 & 3.2 & -22.9 & 6.4 \\
\hline RCD10400 & right metatarsal & A2 & 12.4 & 37.7 & 13.7 & 3.2 & -22.6 & 4.2 \\
\hline
\end{tabular}


dividual was sampled twice in a given layer. Juvenile specimens with unfused epiphysal extremities were discarded due to the possible interference of nursing on the nitrogen isotopic composition. Indeed, young mammals drinking their mother's milk are ${ }^{15} \mathrm{~N}$ enriched relative to the adults of the same species due to the trophic level between milking mother and suckling calf (e.g. Fogel et al., 1989; Bocherens et al., 1994; Balasse et al., 1997). Since the extent of this nursing enrichment varies (Jenkins et al., 2001), we chose to ignore the juvenile specimens in this study. Teeth were avoided as well due to significant intra-individual isotopic variation in cervids that might interfere with palaeoenvironmental interpretation (Bocherens et al., 1994; Bocherens and Mariotti, 1997). For each sample, 200-500-mg chunks of cortical bone were removed by saw, ground to powder and sieved to retain the $\ll 0.7-\mathrm{mm}$ fraction. The collagen extraction protocol follows that presented in Bocherens et al. (1991). Isotopic abundances are expressed as $\delta$ values, as follows: $\delta^{\mathrm{E}} \mathrm{X}=\left(\mathrm{R}_{\text {sample }} / \mathrm{R}_{\text {standard }}-1\right) 1000 \quad(\% 0)$, where $\mathrm{X}$ stands for $\mathrm{C}$ or $\mathrm{N}, \mathrm{E}$ stands for 13 or 15 , respectively, and $\mathrm{R}$ stands for the isotopic ratios ${ }^{13} \mathrm{C} /{ }^{12} \mathrm{C}$ and ${ }^{15} \mathrm{~N} /{ }^{14} \mathrm{~N}$, respectively. The standard, internationally defined, is Vienna-PeeDee Belemnite for carbon and atmospheric nitrogen (AIR) for nitrogen. Analytical error is $0.1 \%$ and $0.2 \%$ for $\delta^{13} \mathrm{C}$ values and $\delta^{15} \mathrm{~N}$ values, respectively. The isotopic measurements have been performed on an elemental analyser $\mathrm{CHN}$ connected to a VG-Optima isotopic ratio mass spectrometer at the Laboratory of Isotopic Biogeochemistry, University of Paris 6, France.

\section{Results}

All the results are presented in Table 2. The extraction yields range from 6.2 to $33.2 \mathrm{mg} . \mathrm{g}^{-1}$. The $\delta^{13} \mathrm{C}$ and $\delta^{15} \mathrm{~N}$ values of red deer bone collagen range from -23.4 to $-19.5 \%$ and from 0.2 to $6.4 \%$, respectively. In the extracted residues, the carbon and the nitrogen amounts range from 36.8 to $42.5 \%$ and from 13.3 to $15.5 \%$, respectively, with all $\mathrm{C} / \mathrm{N}$ ratios ranging from 3.1 to 3.2. All these chemical parameters are well within the range of those of collagen extracted from fresh bones, which indicates that the extracted residues have preserved their original isotopic compositions (DeNiro, 1985; Ambrose, 1990). Moreover, isotopic values do not vary significantly with extraction yield (Fig. 2), thus indicating that the isotopic variations are not due to the selective collagen loss during diagenesis. The isotopic values rather seem to vary according to the layer from which the sample originates. A plotbox shows clearly that collagen from red deer bones from layers $\mathrm{A} 2$ and $\mathrm{A} 3$ present lower $\delta^{13} \mathrm{C}$ values and higher $\delta^{15} \mathrm{~N}$ values than those from layers A4, B, $\mathrm{C}^{\prime} 1$ and D (Fig. 3). A nonparametrical statistical test (Mann-Whitney) shows that both groups of values present highly significant differences $(P \ll 0.0001)$. Within the group of values formed by layers A3 and A2, the $\delta^{13} \mathrm{C}$ values from collagen are exhibiting the same median value in both layers. The $\delta^{15} \mathrm{~N}$ val-

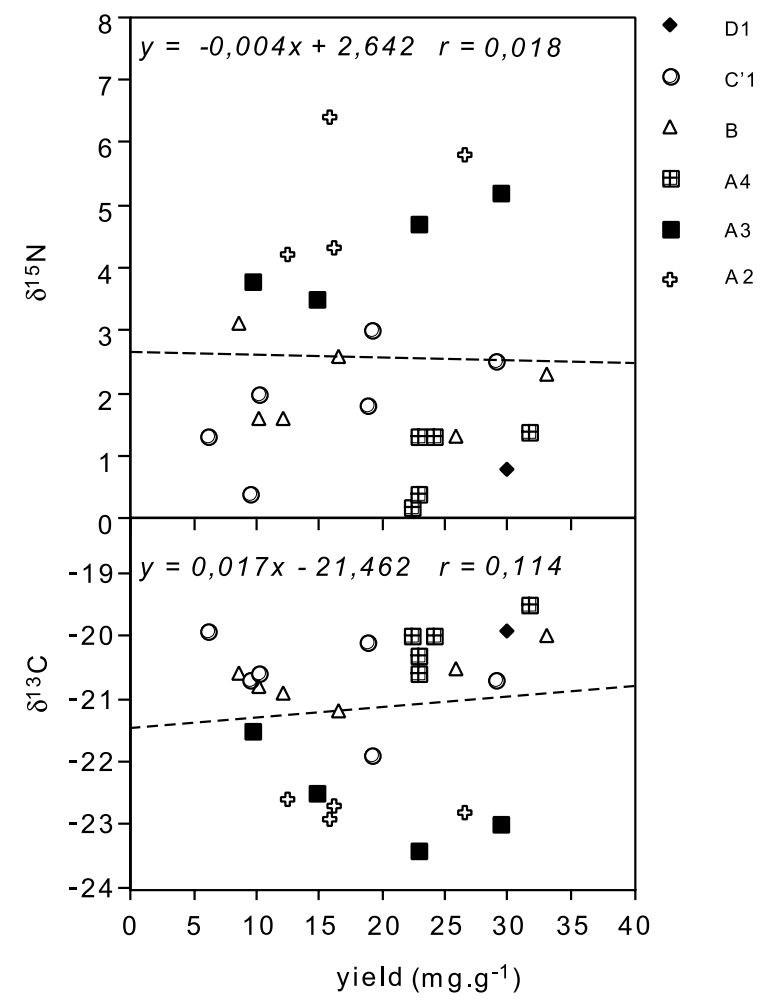

Fig. 2. Variations of red deer bone collagen $\delta^{13} \mathrm{C}$ and $\delta^{15} \mathrm{~N}$ values according to collagen extraction yields in Rochedane specimens. Correlation is not statistically significant since $r$ is lower than $\alpha_{0.05}=0.33$ for $n=26$. 


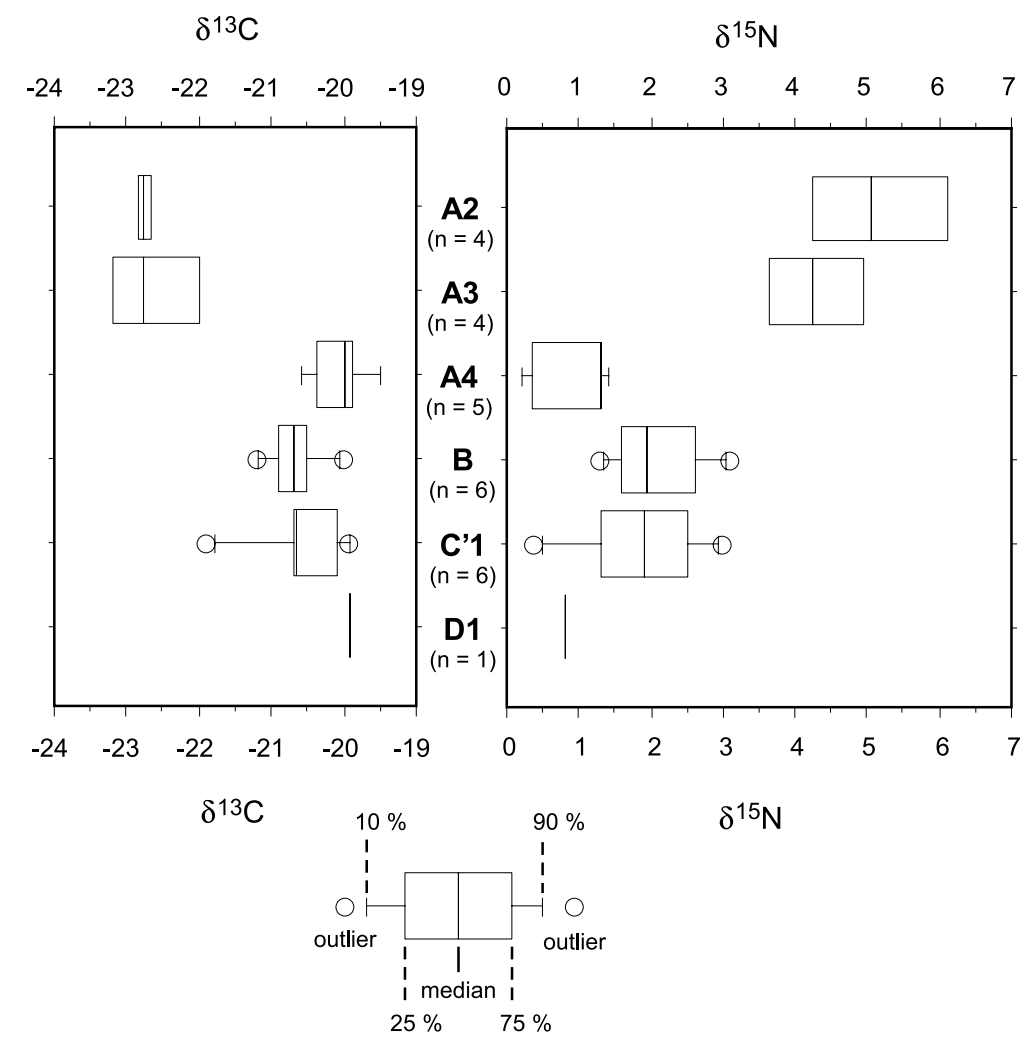

Fig. 3. Plot-box diagrams of red deer bone collagen $\delta^{13} \mathrm{C}$ and $\delta^{15} \mathrm{~N}$ values in the different stratigraphic layers of Rochedane.

ues are slightly higher in collagen from layer A2 than in collagen from layer A3, the average difference being $0.9 \%$, which is not statistically significant $(P=0.2482)$. Within the stratigraphic group formed by layers $\mathrm{A} 4, \mathrm{~B}, \mathrm{C}^{\prime} 1$, and $\mathrm{D}$, statistical tests could be performed for the three first layers, since layer $\mathrm{D}$ yielded only one value. The $\delta^{13} \mathrm{C}$ and $\delta^{15} \mathrm{~N}$ values are not statistically different between layers $\mathrm{B}$ and $\mathrm{C}^{\prime} 1(P=0.6879$ for both values). Statistical tests show that the $\delta^{13} \mathrm{C}$ values are significantly higher and that the $\delta^{15} \mathrm{~N}$ values are significantly lower in layer A4 than in layers B and $\mathrm{C}^{\prime} 1(P \ll 0.05$ in both cases $)$.

\section{Discussion}

\section{1. ${ }^{13} \mathrm{C}$ and vegetation}

The large range of $\delta^{13} \mathrm{C}$ values observed in red deer bone collagen can be linked to the consump- tion of plants growing in different types of plant communities. It is known that $\mathrm{C}_{3}$ plants exhibit a ${ }^{13} \mathrm{C}$ depletion more marked under closed canopies in forested environments than in open environments (e.g. Vogel, 1978; van der Merwe and Medina, 1991). This difference can reach $2-5 \%$ o between plants living under a closed canopy and those living high in the forest canopy (e.g. Schleser and Jayasekera, 1985; Tieszen, 1991; Broadmeadow et al., 1992). The same phenomenon has been observed between plants belonging to the same growth form and even to the same botanical family, living in open habitats or under a closed canopy (Tieszen and Boutton, 1989). This depletion was considered to be due to the recycling of $\mathrm{CO}_{2}$ from respiration and decomposition of organic matter under the canopy (e.g. Vogel, 1978; Medina and Minchin, 1980; van der Merwe and Medina, 1991). More recent studies suggest that this factor represents actually less than 40\% of the observed effect (Schleser and Jayasekera, 
1985; Broadmeadow et al., 1992; Brooks et al., 1997; Buchmann et al., 1997a). These studies emphasise the effect of other factors, such as the $\mathrm{CO}_{2}$ concentration gradient which is at its maximum at floor level (Broadmeadow et al., 1992; Buchmann et al., 1997b), the attenuation of light intensity under the canopy (Schleser and Jayasekera, 1985; Broadmeadow et al., 1992; Brooks et al., 1997), and water availability in forested contexts (Broadmeadow et al., 1992; Brooks et al., 1997). Thus far, most of the studies that demonstrate the difference of $\delta^{13} \mathrm{C}$ values between plants living in the understory and those in open environments have been conducted in tropical and equatorial forests (Tieszen and Boutton, 1988). In this paper, we specifically review the case of forest plants from the temperate and periarctic plant formations from the northern hemisphere. In the case of forests, it is generally claimed that pine forests exhibit $\delta^{13} \mathrm{C}$ values around $3 \%$ enriched on average relative to broadleaf deciduous forests
(Stuiver and Brazuinas, 1987; Garten and Taylor, 1992; Brooks et al., 1997). Recent studies have shown that other parameters have to be taken into account, such as the Leaf Area Index (LAI) and the intensity of atmospheric mixing due to wind circulation in the understory (Buchmann et al., 1997b). A review of published $\delta^{13} \mathrm{C}$ values of plants from different temperate and periarctic plant formations, corrected for post-industrial ${ }^{13} \mathrm{C}$ depletion of atmospheric $\mathrm{CO}_{2}$ using the formula of Feng (1998), modified by Bocherens and Drucker (2003) to set a $\delta^{13} \mathrm{C}$ value of $-7 \%$ for atmospheric $\mathrm{CO}_{2}$, shows clearly that no values more negative than $-27.5 \%$ are reported for plants from open formations, whereas most of the $\delta^{13} \mathrm{C}$ values of plants from the understory of forest formations are more negative than $-27.5 \%$ (Fig. 4). Among the forest formations, the Pinus dominated coniferous forest seems to exhibit less negative $\delta^{13} \mathrm{C}$ values than the other forest types. It is noteworthy that this forest ex-

Coniferous forest, $L A I=3$ to 6
Picea dominated

Fig. 4. Schematic range of $\delta^{13} \mathrm{C}$ values in plants from various temperate and periarctic plant communities in Europe and North America according to their growth types (values from Bocherens, 1992; Mole et al., 1994; Rodière, 1995; Brooks et al., 1997; Buchmann et al., 1997a,b). LAIs are based on the original publications for each plant community and completed by LAI estimates from Scurlock et al. (2001) for Fagus dominated deciduous forest. All the $\delta^{13} \mathrm{C}$ values have been corrected for post-industrial ${ }^{13} \mathrm{C}$ depletion of atmospheric $\mathrm{CO}_{2}$ using the formula of Feng (1998), modified by Bocherens and Drucker (2003), to set a $\delta^{13} \mathrm{C}$ value of $-7 \%$ for atmospheric $\mathrm{CO}_{2}$. 
hibits also the lowest LAI, compared to the Picea dominated coniferous forest and deciduous forests (Fig. 4). Further work on different forest types may lead to the possibility to characterise specific $\delta^{13} \mathrm{C}$ values for plants under different canopy types.

$\delta^{13} \mathrm{C}$ variations in red deer collagen can be interpreted in terms of consumption of plants from different types of plant communities, with a positive shift of $5 \%$ o between the average diet and the collagen isotopic signature (DeNiro and Epstein, 1978; Rodière et al., 1996). An empirical end value for herbivores consuming only plants from a dense-canopy forest can be estimated while using the collagen $\delta^{13} \mathrm{C}$ values of modern roe deer $(\mathrm{Ca}$ preolus capreolus) from the beech forest of Dourdan, France (Rodière et al., 1996). The $\delta^{13} \mathrm{C}$ values of individuals living under the canopy range from -26.1 to $-23.4 \%$ if values obtained on very young specimens are excluded. For a direct comparison with prehistoric deer, it is necessary to take into account the decrease of $\delta^{13} \mathrm{C}_{\text {of }} \mathrm{CO}_{2}$ in the modern atmosphere due to fossil fuel combustion and deforestation (Keeling et al., 1979; Friedli et al., 1986). The $\delta^{13} \mathrm{C}$ value of atmospheric $\mathrm{CO}_{2}$ between 13000 and 8000 yr BP can be estimated at ca. $-7 \%$ o (Leuenberger et al., 1992; Toolin and Eastoe, 1993; van de Water et al., 1994). The forest roe deer from Dourdan lived at the end of the 1980s (Rodière et al., 1996) when atmospheric $\mathrm{CO}_{2}$ had a $\delta^{13} \mathrm{C}$ value of around $-7.9 \%$ (Marino and McElroy, 1991). After correction of this $0.9 \%$ offset, a collagen $\delta^{13} \mathrm{C}$ value of $-22.5 \%$ is a minimum estimate for individuals that consumed only closed-canopy plants. This estimate is consistent with the $\delta^{13} \mathrm{C}$ values measured on bone collagen from modern cervids from the Bialowieza primaeval forest in Poland (Bocherens and Drucker, 2003). In other words, specimens with a collagen $\delta^{13} \mathrm{C}$ value more negative than $-22.5 \%$ consumed a significant amount of plants growing under closed-canopy conditions. Specimens with a $\delta^{13} \mathrm{C}$ value more positive than $-22.5 \%$ probably did not consume plants from closed-canopy vegetation, and consequently were dwelling mostly in open environments such as grassland or open woodland.

In all the layers that were deposited during the
Bölling/Alleröd and the Younger Dryas, i.e. layers D1, $\mathrm{C}^{\prime} 1, \mathrm{~B}$ and $\mathrm{A} 4$, the analysed red deer exhibit $\delta^{13} \mathrm{C}$ values more positive than $-22.5 \%$, and thus appear to have consumed plants from open environments such as tundra, grassland or open woodland. These data contrast with specimens deriving from layer A2, deposited during the Boreal period, which have $\delta^{13} \mathrm{C}$ values more negative than $-22.5 \%$, reflecting the consumption of plants growing under a closed-canopy, typical of a dense forest. Specimens from layer A3, deposited during the Preboreal period, present varying $\delta^{13} \mathrm{C}$ values, lower or higher than $-22.5 \%$, which suggests the consumption of plants from different types of environments, according to the individual deer investigated. Although all deer specimens from the Bölling/Alleröd and the Younger Dryas seem to have dwelled in open environments, some variations of their $\delta^{13} \mathrm{C}$ values may reflect changes in the plant communities. These carbon isotopic changes may reflect $\delta^{13} \mathrm{C}$ fluctuations of the plants under constant atmospheric $\delta^{13} \mathrm{C}$ values, due to physiological adaptations. Alternatively, they may reflect changes in the $\delta^{13} \mathrm{C}$ values of atmospheric $\mathrm{CO}_{2}$. Beerling et al. (1993) document a $1-2 \%$ decrease of the $\delta^{13} \mathrm{C}$ values of Salix herbacea between the Devensian Late-Glacial interstadial (i.e. Bölling/Alleröd) and the Full Glacial and the Devensian Late-Glacial stadial (i.e. Younger Dryas) in Great Britain. However, this work is the only investigation to date describing such a carbon isotopic decrease. Indeed, the Bölling/Alleröd interstadial is instead characterised by a slight increase of the $\delta^{13} \mathrm{C}$ values of atmospheric $\mathrm{CO}_{2}$ (Toolin and Eastoe, 1993). Alternatively, such variations may reflect changes in the plant composition during the Bölling/Alleröd interstadial, which are clearly illustrated by palynological data from the Jura (e.g. de Beaulieu et al., 1994; Bégeot et al., 2000; Richard and Bégeot, 2000; Richard et al., 2000). We will return to this point having first considered the variations in $\delta^{15} \mathrm{~N}$ values.

\section{2. ${ }^{15} \mathrm{~N}$ and environmental factors}

The observed range of $\delta^{15} \mathrm{~N}$ values in red deer collagen exceeds $6 \%$, which is significant since 
the average trophic level enrichment ranges from 3 to $5 \%$ (e.g. Ambrose, 2000; Bocherens and Drucker, 2003). Clearly, this variation cannot be due to a change in trophic level for red deer since this species is unambiguously a plant-eating animal. In previous works dealing with the variations of collagen $\delta^{15} \mathrm{~N}$ values in herbivorous mammals, the main factor explaining these variations was concluded to be aridity: the more arid, the higher the $\delta^{15} \mathrm{~N}$ values (e.g. Ambrose and DeNiro, 1986; Heaton et al., 1986; Sealy et al., 1987; Ambrose, 1991; Gröcke et al., 1997; Bocherens et al., 2000). If we follow the relationship deduced from a study of modern South African herbivorous mammals (Heaton et al., 1986), a change in collagen $\delta^{15} \mathrm{~N}$ values from 0.2 to $6.4 \%$ as observed in Rochedane red deer should correspond to a change in the annual rainfall amount from about 1000 to $600 \mathrm{~mm} / \mathrm{yr}$. Such changes are unrealistic for the Jura during the Late-Glacial and Early Holocene, especially since the most positive $\delta^{15} \mathrm{~N}$ values are measured in specimens with the most negative $\delta^{13} \mathrm{C}$ values indicating a dense forest (Fig. 5). Variations in the $\delta^{15} \mathrm{~N}$ values of plants consumed by red deer are thus the most likely cause for the variations observed in their bone collagen.

In contrast with carbon, there is no obvious environmental parameter that controls the isotopic variations of nitrogen in plants in temperate, boreal and periarctic environments. The $\delta^{15} \mathrm{~N}$ values of plants depend on the source of nitrogen that they use, on its chemical form and on the assimilation mechanism, in particular the possible influence of mycorrhizas (e.g. Högberg et al., 1996; Handley et al., 1998, 1999; Michelsen et al., 1996, 1998; Yoneyama et al., 1998). Except for leguminous plants that preferentially use atmospheric nitrogen fixed by microbial symbiots of their roots and thus have $\delta^{15} \mathrm{~N}$ values systematically close to $0 \%$, the large majority of plants use mainly organic nitrogen or inorganic nitrogen in soil in the form of $\mathrm{NH}_{4}^{+}$and $\mathrm{NO}_{3}^{-}$(e.g. Yoneyama et al., 1998). During the biogeochemical cycle of nitrogen, organic nitrogen is mineralised by micro-organisms as ammonia $\mathrm{NH}_{4}^{+}$and then oxydised into nitrate $\mathrm{NO}_{3}^{-}$. During these chemical reactions, the product is ${ }^{15} \mathrm{~N}$ depleted relative to

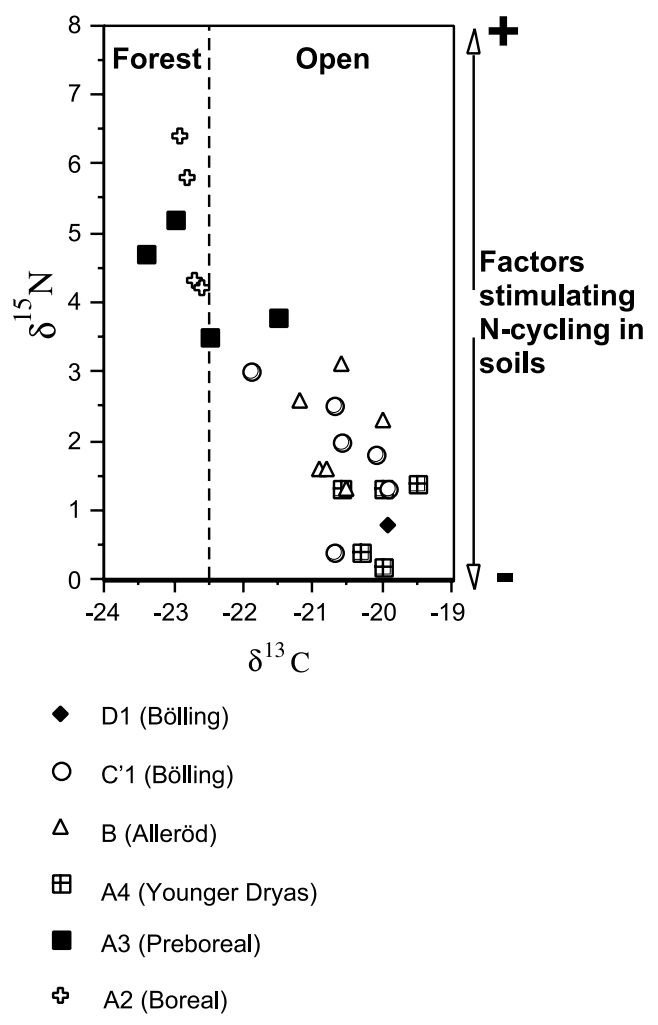

Fig. 5. Variations of red deer bone collagen $\delta^{13} \mathrm{C}$ and $\delta^{15} \mathrm{~N}$ values in Rochedane according to stratigraphic origins.

the substrate, thus $\mathrm{NO}_{3}^{-}$exhibits more negative $\delta^{15} \mathrm{~N}$ values than $\mathrm{NH}_{4}^{+}$, and $\mathrm{NH}_{4}^{+}$presents more negative $\delta^{15} \mathrm{~N}$ values than organic nitrogen. The $\delta^{15} \mathrm{~N}$ values of plants will reflect those of their nitrogen source in the soil. If nitrogen cycling is stimulated, residual inorganic nitrogen will exhibit higher $\delta^{15} \mathrm{~N}$ values. This is because the lighter reaction product is eliminated by absorption by plants and micro-organisms, volatilisation or leaching (Schulze et al., 1994). Examples of stimulation of $\mathrm{N}$ cycling are fertilisation and fires. Indeed, experimental $\mathrm{N}$ fertilisation of forest plants led to increased $\delta^{15} \mathrm{~N}$ values (Johannisson and Högberg, 1994) and $\delta^{15} \mathrm{~N}$ values of plants growing in cultivated fields are more positive than those of forest plants from the same area (e.g. Riga et al., 1970; Hobson, 1999). Moreover, plants growing on parcels after the latter had been burned have more positive $\delta^{15} \mathrm{~N}$ values than those that grow on similar parcels in the 
absence of fires (Grogan et al., 2000). Cold and dry conditions, by contrast, lower activities of $\mathrm{N}$-elimination processes causing a decrease of $\delta^{15} \mathrm{~N}$ values in, for example, plants from hilltops relative to valley bottoms (Peñuelas et al., 1999). Moreover, it has been recognised that soil $\delta^{15} \mathrm{~N}$ values increase with increasing mean annual temperature (Brenner et al., 2001).

Unfortunately, direct comparisons of $\delta^{15} \mathrm{~N}$ values in plants and soils from modern arctic and temperate plant formations do not permit us to decipher the effects of temperature on nitrogen natural isotopic abundances due to the interference of anthropogenic activities in temperate areas, such as $\mathrm{N}$ deposition linked to air pollution and forest harvest (e.g. Schulze et al., 1994; Emmett et al., 1998; Bauer et al., 2000). Due to these complicating factors, a range of $\delta^{15} \mathrm{~N}$ values that can reach $10 \%$ is observed for a given type of plant in a similar type of forest across a transect in Europe (Emmett et al., 1998; Bauer et al., 2000). Such a large range can explain the observed differences in $\delta^{15} \mathrm{~N}$ values of collagen from modern roe deer from beech forests in France (Dourdan) and Poland (Bialowieza), with $\delta^{15} \mathrm{~N}$ values of $-1.5 \pm 0.8 \%$ and $2.1 \pm 1.8 \%$, respectively (Rodière et al., 1996; Bocherens and Drucker, 2003).

In the present study, it is noteworthy that $\delta^{15} \mathrm{~N}$ values of red deer collagen tend to decrease when climatic conditions become harsher, such as at the beginning of the Bölling period and during the Younger Dryas, whereas they tend to increase during the Bölling/Alleröd interstadial and even more during the Preboreal and Boreal periods, at the same time that the $\delta^{13} \mathrm{C}$ values decrease (Fig. 5). It is thus important to discuss the possible mechanisms that may increase the $\delta^{15} \mathrm{~N}$ values of soils and plants in the context of increasing temperatures.

The co-variation between the $\delta^{13} \mathrm{C}$ and $\delta^{15} \mathrm{~N}$ values leads to the interpretation that when plant cover becomes more dense and the $\delta^{13} \mathrm{C}$ values of plant food available to red deer decrease, the nitrogen cycle is stimulated and the increased loss of nitrogen leads to enriched $\delta^{15} \mathrm{~N}$ values in soils, and thus in the plants consumed by red deer. A generalisation of red deer collagen isotopic studies in the Jura will possibly enable us to decipher the environmental parameters that determine the $\delta^{15} \mathrm{~N}$ variations in this region in comparison with its well-known vegetation evolution, as synthesised by Richard et al. (2000).

The Preboreal is one of the key periods in which the co-variation of $\delta^{13} \mathrm{C}$ and $\delta^{15} \mathrm{~N}$ values is similar to the overall co-variation observed for the whole sequence. Red deer consuming forest plants as well as red deer eating plants from open environments have been encountered in this layer. The question regarding the coexistence or succession of these individuals will possibly be solved by the AMS radiocarbon dating of the extracted bone collagen of different individuals with different isotopic compositions which is being carried out, although the occurrence of a ${ }^{14} \mathrm{C}$ plateau from the second part of the Younger Dryas biozone to the first part of the Preboreal biozone (Amman and Lotter, 1989) may create problems.

\subsection{Comparison with the isotopic signatures of other Late-Glacial red deer bones from western Europe}

It is interesting to compare the isotopic compositions measured on red deer collagen from Rochedane with those previously obtained for the same species in Pont d'Ambon, an archaeological site located in the Dordogne, southwestern France, which yielded red deer bones of Late-Glacial age (Table 3; Fig. 6). The $\delta^{13} \mathrm{C}$ values exhibit similar ranges at both sites during the Bölling/Alleröd interstadial and the Younger Dryas stadial, with perhaps more pronounced variations in Rochedane. The $\delta^{13} \mathrm{C}$ values decrease during the Preboreal in Pont d'Ambon, but not as much as in Rochedane (Fig. 6). Actually, only one specimen from Pont d'Ambon yielded $\delta^{13} \mathrm{C}$ values more negative than $-22.5 \%$, indicating the consumption of plants from a rather dense-canopy forest (Drucker and Célérier, 2001). The $\delta^{15} \mathrm{~N}$ values of red deer from Pont d'Ambon are more positive than those from Rochedane during the Bölling/ Alleröd and Younger Dryas periods (Fig. 6). In contrast, the nitrogen isotopic compositions are similar for the Preboreal period. For carbon and 
Table 3

List of isotopic results obtained on red deer bone collagen from different archaeological layers at Pont d'Ambon

\begin{tabular}{|c|c|c|c|c|}
\hline Sample number & Layer & Chronozone & $\begin{array}{l}\delta^{13} \mathrm{C} \\
(\% 0)\end{array}$ & $\begin{array}{l}\delta^{15} \mathrm{~N} \\
(\% 0) \\
\end{array}$ \\
\hline PAM200 & 2 & Preboreal & -20.3 & 3.9 \\
\hline PAM300 & 2 & Preboreal & -23.4 & 4.0 \\
\hline PAM400 & 2 & Preboreal & -20.2 & 3.1 \\
\hline PAM500 & 2 & Preboreal & -20.5 & 4.5 \\
\hline PAM1300 & 3 & Younger Dryas & -21.0 & 3.3 \\
\hline PAM 1400 & 3 & Younger Dryas & -20.3 & 3.0 \\
\hline PAM1500 & 3 & Younger Dryas & -20.6 & 3.1 \\
\hline PAM2100 & $3 \mathrm{~A}$ sup & Younger Dryas & -20.3 & 2.5 \\
\hline PAM 2200 & $3 \mathrm{~A}$ & Younger Dryas & -20.3 & 3.3 \\
\hline PAM2300 & $3 \mathrm{~A}$ & Younger Dryas & -20.4 & 2.8 \\
\hline PAM 2400 & $3 \mathrm{~A}$ & Younger Dryas & -20.5 & 4.7 \\
\hline PAM 2500 & $3 \mathrm{~A}$ & Younger Dryas & -20.8 & 3.0 \\
\hline PAM2800 & $3 \mathrm{~B}$ & Bölling/Alleröd & -20.7 & 4.4 \\
\hline PAM2900 & $3 \mathrm{~B}$ & Bölling/Alleröd & -19.9 & 4.0 \\
\hline PAM3000 & $3 \mathrm{~B}$ & Bölling/Alleröd & -20.6 & 3.5 \\
\hline PAM3300 & 4 & Bölling/Alleröd & -20.8 & 3.6 \\
\hline PAM3400 & 4 & Bölling/Alleröd & -20.2 & 2.9 \\
\hline PAM3500 & 4 & Bölling/Alleröd & -20.3 & 3.6 \\
\hline
\end{tabular}

Carbon and nitrogen isotopic values are from Drucker and Célérier (2001) and Drucker (2001), respectively.

nitrogen isotopic compositions, the variations are more pronounced in the Jurassian Massif, as exemplified by the case of Rochedane, than in Aquitaine, as seen in Pont d'Ambon. Rochedane, which is located at a higher altitude and, consequently, much closer to the glacier front than Pont d'Ambon, probably experienced more pronounced environmental changes. For instance, the
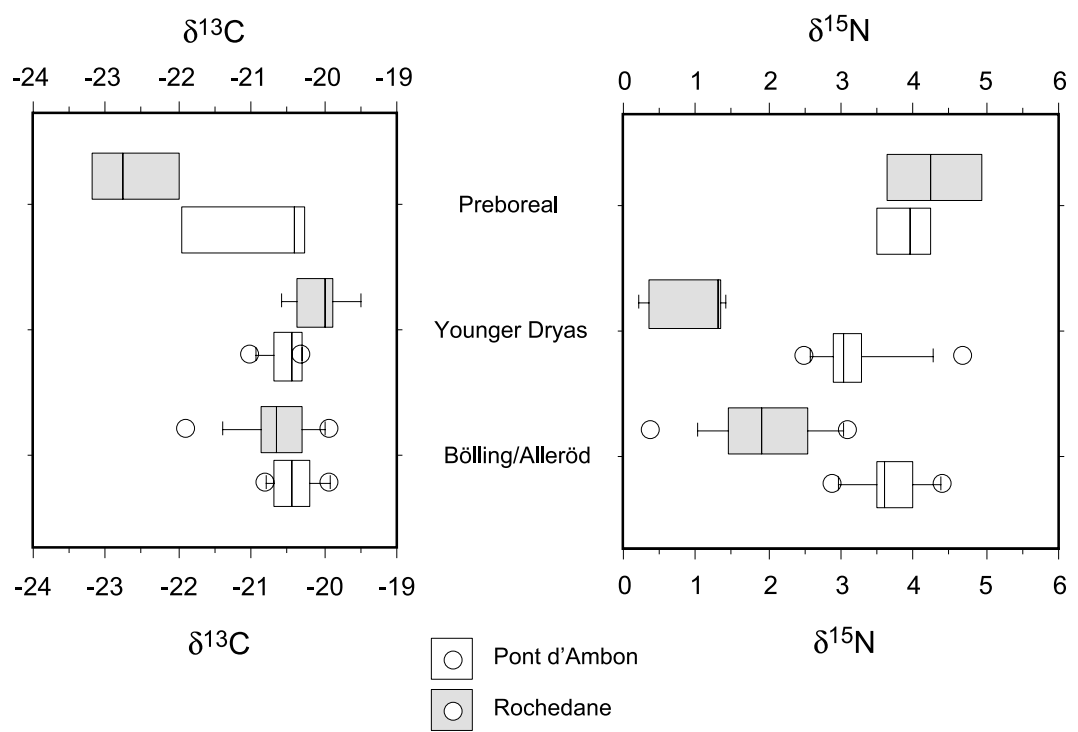

Fig. 6. Plot-box diagrams of red deer bone collagen $\delta^{13} \mathrm{C}$ and $\delta^{15} \mathrm{~N}$ values during different periods in Rochedane and Pont d'Ambon. The Bölling and Alleröd have been plotted as one period since they are not clearly distinguishable in southwestern France (discussion in Drucker and Célérier, 2001). 
Table 4

Carbon isotopic abundance measured on radiocarbon dated red deer bone collagen from different archaeological sites in Great Britain

\begin{tabular}{|c|c|c|c|c|c|}
\hline Site & Age BP & Laboratory number & Tissue & $\begin{array}{l}\delta^{13} \mathrm{C} \\
(\% \circ)\end{array}$ & Reference \\
\hline Wandsworth & $9050 \pm 85$ & OxA-3736 & antler & -20.1 & Archaeometry 35 (2), 1993, 305-326a \\
\hline Thatcham V & $9510 \pm 90$ & OxA-5191 & bone & -21.8 & Archaeometry $38(1), 1996,181-207^{b}$ \\
\hline Three Holes Caves & $10020 \pm 80$ & OxA-4478 & bone & -18.4 & Archaeometry 38 (2), 1996, 391-415 c \\
\hline Hyaena Den & $11320 \pm 120$ & OxA-5700 & bone & -20.2 & Archaeometry 38 (2), 1996, 391-415 c \\
\hline Three Holes Caves & $11980 \pm 100$ & OxA-3891 & bone & -20.8 & Archaeometry 38 (2), 1996, 391-415 c \\
\hline Pixie's Hole Cave & $12070 \pm 90$ & OxA-5796 & bone & -19.9 & Archaeometry 40 (1), 1998, 227-239d \\
\hline Gough's Cave & $12490 \pm 120$ & OxA-3412 & bone & -20.8 & Archaeometry 36 (2), 1994, 337-374 \\
\hline Gough's Cave & $12490 \pm 140$ & OxA-3413 & bone & -18.7 & Archaeometry 36 (2), 1994, 337-374 \\
\hline
\end{tabular}

a http://users.ox.ac.uk/ orau/dl_am17.html.

b http://users.ox.ac.uk/ orau/dl_am21.html.

c http://users.ox.ac.uk/ orau/dl_am22.html.

d http://users.ox.ac.uk/ orau/dl_am25.html.

e http://users.ox.ac.uk/ orau/dl_am18.html.

intensity of nitrogen cycling processes was probably more important in Pont d'Ambon than in Rochedane during the Bölling/Alleröd and the Younger Dryas periods, but the levels became similar in both areas during the Preboreal warming period.

Some red deer bone collagen carbon isotopic compositions from British archaeological sites of similar age as Rochedane could be extracted from the database of the Oxford Radiocarbon Laboratory (Table 4). It is noteworthy that all the specimens present $\delta^{13} \mathrm{C}$ values clearly more positive than $-22.5 \%$, thus indicating specimens dwelling in open environments, as can be expected for this area during the Late-Glacial.

\section{Conclusions}

The results of the present study demonstrated that carbon and nitrogen isotopic composition of red deer bone collagen is a valuable tool for reconstructing palaeoenvironments in Late-Glacial and Holocene Europe. Due to the ecological flexibility of red deer, the occurrence of this species at a given archaeological site cannot be used as a palaeoenvironmental indicator. However, the isotopic signatures of its bones provide a powerful tool to reconstruct the landscape where the animals used to live and were hunted. Use of carbon isotopic signatures as markers of vegetation types could be foreseen. However, the relationship between the nitrogen isotopic signatures of an herbivorous species and specific characteristics of nitrogen cycling in soils had not yet been established. The Late-Glacial and Early Holocene sequence of Rochedane spans the whole range of environments that can be expected in western Europe during the last fifteen thousand years. Palaeoenvironmental reconstruction of periarctic and temperate terrestrial ecosystems will certainly benefit from this novel approach.

\section{Acknowledgements}

We thank the CNRS for its support through the MOTIVE committee of the CNRS programme PEVS ('Programme Environnement, Vie et Société'). Thanks are due also to André Thévenin for his autorisation to sample bone from the Rochedane material. Furthermore, we are thankful to G.J. van Klinken for very constructive comments and to M. Collins for accepting to polish the English language. This is contribution ISEM 2003-28.

\section{References}

Ambrose, S.H., 1990. Preparation and characterization of bone and tooth collagen for isotopic analysis. J. Archaeol. Sci. 17, 431-451. 
Ambrose, S.H., 1991. Effects of diet, climate and physiology on nitrogen isotope abundances in terrestrial foodwebs. J. Archaeol. Sci. 18, 293-317.

Ambrose, S.H., 2000. Controlled diet and climate experiments on nitrogen isotope ratios in rats. In: Ambrose, S.H., Katzenberg, M.A. (Eds.), Biogeochemical Approaches to Paleodietary Analysis, Kluwer Academic/Plenum, New York, pp. 243-259.

Ambrose, S.H., DeNiro, M.J., 1986. The isotopic ecology of East African mammals. Oecologia 69, 395-406.

Ambrose, S.H., DeNiro, M.J., 1989. Climate and habitat reconstruction using stable carbon and nitrogen isotope ratios of collagen in prehistoric herbivore teeth from Kenya. Quat. Res. 31, 407-422.

Amman, B., Lotter, A.F., 1989. Late-Glacial radiocarbon- and palynostratigraphy on the Swiss Plateau. Boreas 18, 109126.

Amman, B., Birks, H.J.B., Brooks, S.J., Eicher, U., von Grafenstein, U., Hofmann, W., Lemdahl, G., Schwander, J., Tobolski, K., Wick, L., 2000. Quantification of biotic responses to rapid climatic changes around the Younger Dryas - A synthesis. Palaeogeogr. Palaeoclimatol. Palaeoecol. 159, 313-347.

Balasse, M., Bocherens, H., Tresset, A., Mariotti, A., Vigne, J.-D., 1997. Émergence de la production laitière au néolithique? Contribution de l'analyse isotopique d'ossements de bovins archéologiques. C. R. Acad. Sci. Paris 325, 10051010.

Bauer, G.A., Gebauer, G., Harrison, A.F., Högberg, P., Högbom, L., Schinkel, H., Taylor, A.F.S., Novak, M., Buzek, F., Harkness, D., Persson, T., Schulze, E.-D., 2000. Biotic and abiotic controls over ecosystem cycling of stable natural nitrogen, carbon and sulphur isotopes. Ecol. Stud. 142, 189214.

Beerling, D.J., Mattey, D.P., Chaloner, W.G., 1993. Shifts in the $\delta^{13} \mathrm{C}$ composition of Salix herbacea $\mathrm{L}$. leaves in response to spatial and temporal gradients of atmospheric $\mathrm{CO}_{2}$ concentration. Proc. R. Soc. Lond. B. 253, 53-60.

Bégeot, C., Richard, H., Ruffaldi, P., Bossuet, G., 2000. Enregistrement pollinique des changements climatiques de l'Interstade Bölling/Alleröd dans l'est de la France. Bull. Soc. Géol. Fr. 171, 51-58.

Björk, S., Walker, M.J.C., Cwynar, L.C., Johnsen, S., Knudsen, K.-L., Lowe, J.J., Wohlfarth, B., INTIMATE Members, 1998. An event stratigraphy for the Last Termination in the North Altlantic region base on the Greenland ice-core record: A proposal by the INTIMATE group. J. Quat. Sci. 13, 283-292.

Bocherens, H., 1992. Biogéochimie isotopique $\left({ }^{13} \mathrm{C},{ }^{15} \mathrm{~N},{ }^{18} \mathrm{O}\right)$ et Paléontologie des Vertébrés: Applications à l'étude des réseaux trophiques révolus et des paléoenvironnements. Unpubl. Ph.D. Thesis, Univ. Paris 6, Mémoire des Sciences de la Terre 92-6, $317 \mathrm{pp}$.

Bocherens, H., Drucker, D., 2003. Trophic level isotopic enrichments for carbon and nitrogen in collagen: Case studies from recent and ancient terrestrial ecosystems. Int. J. Osteoarchaeol. 13, 46-53.
Bocherens, H., Mariotti, A., 1997. Comments on: Diet, physiology and ecology of fossil mammals as inferred from stable carbon and nitrogen isotope biochemistry: Implications for Pleistocene bears by Bocherens et al. - Reply. Palaeogeogr. Palaeoclimatol. Palaeoecol. 128, 362-364.

Bocherens, H., Fizet, M., Mariotti, A., Lange-Badré, B., Vandermeersch, B., Borel, J.P., Bellon, G., 1991. Isotopic biogeochemistry $\left({ }^{13} \mathrm{C},{ }^{15} \mathrm{~N}\right)$ of fossil vertebrate collagen: Implications for the study of fossil food web including Neandertal Man. J. Hum. Evol. 20, 481-492.

Bocherens, H., Fizet, M., Mariotti, A., 1994. Diet, physiology and ecology of fossil mammals as inferred by stable carbon and nitrogen isotopes biogeochemistry: Implications for Pleistocene bears. Palaeogeogr. Palaeoclimatol. Palaeoecol. 107, 213-225.

Bocherens, H., Mashkour, M., Billiou, D., 2000. Palaeoenvironmental and archaeological implications of isotopic analyses $\left({ }^{13} \mathrm{C},{ }^{15} \mathrm{~N}\right)$ from Neolithic to Present in Qazvin Plain (Iran). Env. Archaeol. 5, 1-19.

Brenner, D.L., Amundson, R., Baisden, W.T., Kendall, C., Harden, J., 2001. Soil $\mathrm{N}$ and ${ }^{15} \mathrm{~N}$ variation with time in a California annual grassland ecosystem. Geochim. Cosmochim. Acta 65, 4171-4186.

Bridault, A., 1990. Epipaléolithique et Mésolithique de l'Est de la France et du Bassin Parisien: Que dit la faune? Rev. Archéol. Est 41, 213-222.

Bridault, A., 1997. Chasseurs, ressources animales et milieux dans le nord de la France de la fin du Paléolithique à la fin du Mésolithique: Problématique et état de la recherche. In: Fagnart, J.-P., Thévenin, A. (Eds.) Le Tardiglaciaire en Europe Protohistoire, C.T.H.S.: Paris, pp. 165-176.

Bridault, A., Chaix, L., Pion, G., Oberlin, C., Thiebault, S., Argant, J., 2000. Position chronologique du renne (Rangifer tarandus L.) à la fin du Tardiglaciaire dans les Alpes du Nord françaises et le Jura méridional. In: Pion, G. (Ed.), Actes de la table ronde de Chambéry 12-13 mars 1999, Le Paléolithique supérieur récent: nouvelles données sur le peuplement et l'environment. Mém. Soc. préhist. fr. 26, 47-57.

Bridault, A., Chaix, L., 2002. Ruptures et équilibres dans la grande faune à la fin du Pléistocène et durant l'Holocène ancien en Europe occidentale. In: Richard, H., Vignot, A. (Eds.), Equilibres et ruptures dans les écosystèmes depuis 20000 ans en Europe de l'Ouest. Collection Annales Littéraires, Série 'Environnement, Sociétés et Archéologie', Presses Universitaires Franc-Comtoises, Besançon, 3, pp. 53-60.

Broadmeadow, M.S.J., Griffiths, H., Maxwell, C., Borland, A.M., 1992. The carbon isotope ratio of plant organic material reflects temporal and spatial variations in $\mathrm{CO}_{2}$ within tropical forest formations in Trinidad. Oecologia 89, 435-441.

Brooks, J.R., Flanagan, L.B., Buchmann, N., Ehleringer, J.R., 1997. Carbon isotope composition of boreal plants: Functional grouping of life forms. Oecologia 110, 301-311.

Buchmann, N., Guehl, J.-M., Barigah, T.S., Ehleringer, J.R., 1997a. Interseasonal comparison of $\mathrm{CO}_{2}$ concentrations, isotopic composition and carbon dynamics in an Amazonian rainforest (French Guiana). Oecologia 110, 120-131. 
Buchmann, N., Wen-Yuan, K., Ehleringer, J.R., 1997b. Influence of stand structure on carbon-13 of vegetation, soils, and canopy air within decideous and evergreen forests in Utah, United States. Oecologia 110, 109-119.

de Beaulieu, J.L., Richard, H., Ruffaldi, P., Clerc, J., 1994. History of vegetation, climate and human action in the French Alps and the Jura over the last 15,000 years. Dissert. Bot. 234, 253-275.

DeNiro, M.J., 1985. Postmortem preservation and alteration of in vivo bone collagen isotope ratios in relation to palaeodietary reconstruction. Nature 317, 806-809.

DeNiro, M.J., Epstein, S., 1978. Influence of diet on the distribution of carbon isotopes in animals. Geochim. Cosmochim. Acta 42, 495-506.

Drucker, D., 2001. Validation méthodologique de l'analyse isotopique d'ossements fossiles et apports aux reconstitutions paléoécologiques du Paléolithique supérieur du sudouest de la France. Unpubl. Ph.D. Thesis, Université Paris 6, $222 \mathrm{pp}$.

Drucker, D., Célérier, G., 2001. Teneurs en carbone-13 du collagène de grands mammifères du site de Pont d'Ambon (Dordogne, France): Implications pour l'environnement et son exploitation au Tardiglaciaire dans le sud-ouest de la France. Paleo 13, 145-153.

Emmett, B.A., Kjønaas, O.J., Gundersen, P., Koopmans, C., Tietema, A., Sleep, D., 1998. Natural abundance of ${ }^{15} \mathrm{~N}$ in forests across a nitrogen deposition gradient. Forest Ecol. Manag. 101, 9-18.

Evin, J., Marien, G., Pachiaudi, C., 1978. Lyon Natural Radiocarbon Measurements VII. Radiocarbon 20, 19-57.

Fernandez, J., Markgraf, V., Panarello, H.O., Albero, M., Angiolini, F.E., Valencio, S., Arriaga, M., 1991. Late Pleistocene/Early Holocene environments and climates, fauna, and human occupation in the Argentine Altiplano. Geoarchaeology 6, 251-272.

Feng, X., 1998. Long-term ci/ca response of trees in western North America to atmospheric $\mathrm{CO}_{2}$ concentration derived from carbon isotope chronologies. Oecologia 117, 19-25.

Floss, H., 2000. La fin du Paléolithique en Rhénanie (Magdalénien, groupes à Federmesser, Ahrensbourgien). L'évolution $\mathrm{du}$ choix des matières premières lithiques, reflet d'un profond changement du climat et du comportement humain. Mém. Mus. Préhist. Ile de France 7, 87-96.

Fogel, M.L., Tuross, N., Owsley, D.W., 1989. Nitrogen isotope traces of human lactation in modern and archeological populations. Ann. Rep. Dir. Geophys. Lab., Carnegie Inst. 1988-1989, pp. 111-117.

Friedli, H., Lötscher, H., Oeschger, H., Siegenthaler, U., Stauffer, B., 1986. Ice core record of the ${ }^{13} \mathrm{C} /{ }^{12} \mathrm{C}$ ratio of the atmospheric $\mathrm{CO}_{2}$ in the past two centuries. Nature 324, 237-238.

Garten, C.T., Taylor, G.E., 1992. Foliar $\delta^{13} \mathrm{C}$ within a temperate deciduous forest: Spatial, temporal and species sources of variations. Oecologia 90, 1-7.

Gröcke, D.R., Bocherens, H., Mariotti, A., 1997. Annual rainfall and nitrogen-isotope correlation in Macropod collagen:
Application as a paleoprecipitation indicator. Earth Planet. Sci. Lett. 153, 279-285.

Grogan, P., Bruns, T.D., Chapin, F.S., III, 2000. Fire effects on ecosystem nitrogen cycling in a Californian bishop pine forest. Oecologia 122, 537-544.

Handley, L.L., Scrimgeour, C.M., Raven, J.A., 1998. ${ }^{15} \mathrm{~N}$ at natural abundance levels in terrestrial vascular plants: A précis. In: Griffiths, H. (Ed.), Stables Isotopes. BIOS, Oxford, pp. 89-98.

Handley, L.L., Azcon, A., Ruiz Lozano, J.M., Scrimgeour, C.M., 1999. Plant $\delta^{15} \mathrm{~N}$ associated with arbuscular mycorrhization, drought and nitrogen deficiency. Rapid Comm. Mass Spectr. 13, 1320-1324.

Heaton, T.H.E., Vogel, J.C., Chevallerie, G.v.l., Collett, G., 1986. Climatic influence on the isotopic composition of bone nitrogen. Nature 322, 822-824.

Heptner, V.G., Nasimovich, A.A., Bannikov, A.G., 1989. Mammals of the Soviet Union, vol. 1. Ungulates. Brill, Leiden.

Hobson, K.A., 1999. Stable-carbon and nitrogen isotope ratios of songbirds feathers grown in two terrestrial biomes: Implications for evaluating trophic relationships and breeding origins. Condor 101, 799-805.

Högberg, P., Högbom, L., Schinkel, H., Högberg, M., Johannisson, C., Wallmark, H., 1996. ${ }^{15} \mathrm{~N}$ abundance in surface soils, roots and mycorrhizas in profiles of European forest soils. Oecologia 108, 207-214.

Jenkins, S.G., Partridge, S.T., Stephensson, T.R., Farley, S.D., Robbins, C.T., 2001. Nitrogen and carbon isotope fractionation between mothers, neonates, and nursing offspring. Oecologia 129, 336-341.

Johannisson, C., Högberg, P., 1994. ${ }^{15} \mathrm{~N}$ abundance of soils and plants along an experimentally induced forest nitrogen supply gradient. Oecologia 97, 322-325.

Keeling, C.D., Bacastow, R.B., Carter, A.F., Piper, S.C., Whorf, T.P., Heimann, M., Mook, W.G., Roeloffzen, H., 1979. A three-dimensional model of atmospheric $\mathrm{CO}_{2}$ transport based on observed winds: 1 . Analysis of observational data. Geophys. Monogr. 55, 165-236.

Leesch, D., 2000. Le Tardiglaciaire en Suisse: Corrélation des données paléoenvironnementales et archéologiques. Mém. Mus. Préhist. Ile de France 7, 217-221.

Lee-Thorp, J.A., Beaumont, P.B., 1995. Vegetation and seasonality shifts during the Late Quaternary deduced from ${ }^{13} \mathrm{C} /{ }^{12} \mathrm{C}$ ratios of grazers at Equus Cave, South Africa. Quat. Res. 43, 426-432.

Leuenberger, M., Siegenthaler, U., Langway, C.C., 1992. Carbon isotope composition of atmospheric $\mathrm{CO}_{2}$ during the Last Ice Age from an Antarctic ice core. Nature 357, 488490.

Magny, M., 1995. Successive oceanic and solar forcing indicated by Younger Dryas and Early Holocene climatic oscillations in the Jura. Quat. Res. 43, 279-285.

Marino, B.D., McElroy, M.B., 1991. Isotopic composition of atmospheric $\mathrm{CO}_{2}$ inferred from carbon in $\mathrm{C} 4$ plant cellulose. Nature 349, 127-131. 
Mateu Andrès, I., 1993. A revised list of the European $\mathrm{C}_{4}$ plants. Photosynthetica 26, 323-331.

Medina, E., Minchin, P., 1980. Stratification of $\delta^{13} \mathrm{C}$ values of leaves in Amazonian rain forests. Oecologia 45, 377-378.

Michelsen, A., Schmidt, I.K., Jonasson, S., Quarmby, C., Sleep, D., 1996. Leaf ${ }^{15} \mathrm{~N}$ abundance of subarctic plants provides field evidence that ericoid, ectomycorrhizal and non- and arbuscular mycorrhizal species access different sources of soil nitrogen. Oecologia 105, 53-63.

Michelsen, A., Quarmby, C., Sleep, D., Jonasson, S., 1998. Vascular plant ${ }^{15} \mathrm{~N}$ natural abundance in heath and forest tundra ecosystems is closely correlated with presence and type of mycorrhizal fungi in roots. Oecologia 115, 406-418.

Mole, S., Joern, A., O’Leary, M.H., Madhavan, S., 1994. Spatial and temporal variation in carbon isotope discrimination in prairie graminoids. Oecologia 97, 316-321.

Pate, F.D., Noble, A.H., 2000. Geographic distribution of $\mathrm{C}_{3}$ and $\mathrm{C}_{4}$ grasses recorded from stable carbon isotope values of bone collagen of South Australian herbivores. Aust. J. Bot. 48, 203-207.

Peñuelas, J., Filella, I., Terradas, J., 1999. Variability of plant nitrogen and water use in a $100-\mathrm{m}$ transect of a subdesertic depression of the Ebro valley (Spain) characterized by leaf $\delta^{13} \mathrm{C}$ and $\delta^{15} \mathrm{~N}$. Acta Oecol. 20, 119-123.

Richard, H., Bégeot, C., 2000. Le tardiglaciaire du Massif Jurassien: Bilan et perspectives de recherche. Quaternaire 11, 145-154.

Richard, H., Bégeot, C., Gauthier, É., Ruffaldi, P., 2000. Evolution du couvert végétal du Tardiglaciaire et du début de l'Holocène sur la chaîne Jurassienne: Nouveaux résultats. In: Cupillard, C., Richard, A. (Eds.), Les derniers chasseurs-cueilleurs du Massif Jurassien et de ses marges (13000-5500 avant Jésus-Christ). Presses Universitaires Franc-Comtoises, Besançon, pp. 29-36.

Riga, A., Van Praag, H.J., Brigode, N., 1970. Rapport isotopique naturel de l'azote dans quelques sols forestiers et agricoles de Belgique soumis à divers traitements culturaux. Geoderma 6, 213-222.

Rodière, É., 1995. Variation des abondances isotopiques naturelles au sein d'une population de chevreuils (Capreolus capreolus L.). Unpubl. M.Sc. Thesis (DEA de Biodiversité, Génétique et Evolution), Univ. Paris 6, 36 pp.

Rodière, É., Bocherens, H., Angibault, J.-M., Mariotti, A., 1996. Particularités isotopiques chez le chevreuil (Capreolus capreolus L.): Implications pour les reconstitutions paléoenvironnementales. C. R. Acad. Sci. Paris 323, 179-185.

Schleser, G.H., Jayasekera, R., 1985. $\delta^{13}$ C-variations of leaves in forests as an indication of reassimilated $\mathrm{CO}_{2}$ from the soil. Oecologia 65, 536-542.

Schulze, E.-D., Chapin, F.S., III, Gebauer, G., 1994. Nitrogen nutrition and isotope differences among life forms at the northern treeline of Alaska. Oecologia 100, 406-412.

Scurlock, J.M.O., Asner, G.P., Gower, S.T., 2001. Worldwide historical estimates and bibliography of Leaf Area Index, 1932-2000. Data set (http://www.daac.ornl.gov).

Sealy, J.C., van der Merwe, N.J., Lee-Thorp, J.A., Lanham, J.L., 1987. Nitrogen isotopic ecology in southern Africa: Implications for environmental and dietary tracing. Geochim. Cosmochim. Acta 51, 2707-2717.

Smith, C., 1992. Late Stone Age Hunters of the British Isles. Routledge, London, 206 pp.

Stuiver, M., Brazuinas, T.F., 1987. Tree cellulose ${ }^{13} \mathrm{C} /{ }^{12} \mathrm{C}$ isotope ratios and climatic change. Nature 328, 58-60.

Stuiver, M., Reimer, P.J., Bard, E., Beck, J.W., Burr, G.S., Hughen, K.A., Kromer, B., McCormac, F.G., van der Plicht, J., Spurk, M., 1998. INTCAL98 Radiocarbon Age Calibration, 24,000-0 cal BP. Radiocarbon 40, 1041-1083.

Thévenin, A., 1982. Rochedane. L'azilien, l'Epipaléolithique de l'Est de la France et les civilisations épipaléolithiques de l'Europe occidentale. Thèse, Université des Sciences humaines de Strasbourg, Mémoire de la Faculté des Sciences sociales, Ethnologie, 2 vols., 845 pp.

Thévenin, A., Sainty, J., 1998. L'abri de Rochedane à Villarssous-Damjoux (Doubs). In: Cupillard, C., Richard, A. (Eds.), Les derniers chasseurs-cueilleurs du Massif Jurassien et de ses marges (13000-5500 avant Jésus-Christ). Presses Universitaires Franc-Comtoises, Besançon, pp. 104-105.

Tieszen, L.L., 1991. Natural variations in the carbon isotope values of plants: Implications for archaeology, ecology, and paleoecology. J. Archaeol. Sci. 18, 227-248.

Tieszen, L.L., Boutton, T.W., 1989. Stable carbon isotopes in terrestrial ecosystem research. In: Rundell, P.W., Ehleringer, J.R., Nagy, K.A. (Eds.), Stable Isotopes in Ecological Research. Springer, New York, pp. 167-195.

Toolin, L.J., Eastoe, T., 1993. Late Pleistocene-Recent atmospheric $\delta^{13} \mathrm{C}$ record in $\mathrm{C}_{4}$ grasses. Radiocarbon 35, 263-269.

van der Merwe, N.J., Medina, E., 1991. The canopy effect, carbon isotope ratios and foodwebs in Amazonia. J. Archaeol. Sci. 18, 249-259.

van de Water, P.K., Leavitt, S.W., Betancourt, J.L., 1994 Trends in stomatal density and ${ }^{13} \mathrm{C} /{ }^{12} \mathrm{C}$ ratios of Pinus flexilis needles during last Glacial-Interglacial cycle. Science 264, 239-243.

Vogel, J.C., 1978. Recycling of carbon in a forest environment. Ecologia Plantarum 13, 89-94.

Yoneyama, T., Jujiwara, H., Wilson, J.M., 1998. Variations in fractionation of carbon and nitrogen isotopes in higher plants: $\mathrm{N}$ metabolism and partitioning in phloem and $\mathrm{xy}-$ lem. In: Griffiths, H. (Ed.), Stables Isotopes. BIOS, Oxford, pp. $99-109$. 